\section{A produção do espaço na região do MATOPIBA: violência, transnacionais imobiliárias agrícolas e capital fictício}

\section{The Space Production in the MATOPIBA Region, Brazil: Violence, Transnational Real Estate Dealers in Agriculture and Fictitious Capital}

\section{DOI: 10.5752/P.2317-773X.2017v5.n2.p155}

Fábio Teixeira Pitta'

Cássio Arruda Boechat ${ }^{2}$

Maria Luisa Mendonça ${ }^{3}$

Recebido em: 15 de agosto de 2017.

Aceito em: 25 de outubro de 2017.

\section{RESUMO}

O presente artigo visa dissertar sobre a presença recente de transnacionais imobiliárias agrícolas na região conhecida por MATOPIBA. A partir do movimento metodológico de crítica da totalidade concreta (SCHOLZ, 2016), observa-se a possibilidade de tais transnacionais investirem na terra como ativo financeiro à parte, ao moverem a subida de seu preço de forma especulativa. Isso ocorre como processo de crise da acumulação capitalista, que se caracteriza pela expulsão do trabalho do processo produtivo, a partir da década de 1970 . Após o ciclo de alta dos preços das commodities nos mercados internacionais, de 2002 a 2012 (com queda mais acentuada a partir de 2014), e da reversão deste ciclo, nota-se o "descolamento" entre os preços das commodities e os da terra. Os investimentos na especulação financeira em terra atingem o MATOPIBA, no século XXI, locus de investimento privilegiado de diversas transnacionais, especialmente após a crise capitalista de 2008. O baixo custo para formação das fazendas por causa da e a partir de grilagem de terras e a rápida subida do preço da terra nos anos recentes retroalimentaram tal subida e fomentaram a procura transnacional atual por tal tipo de investimento, permitindo que seu preço continuasse a subir de forma independente em relação ao do preço das commodities nos mercados de futuros internacionais.

Palavras-chave: Land grabbing. MATOPIBA. Produção fictícia do espaço. Crise do capital. Transnacionais imobiliárias agrícolas.

\section{ABSTRACT}

The following paper aims at dealing with the presence of transnational rural real estate companies in the region known as MATOPIBA. From the methodological movement of the critique of concrete totality (SCHOLZ, 2016), we here observe the possibility of such transnational companies invest in land as an autonomous financial asset, moving the increase of its price in a speculative way. This seems to occur as a process of crisis of the capitalistic accumulation,
1. Fábio Teixeira Pitta é Pós-doutorando do Departamento de Geografia Humana, FFLCH, Universidade de São Paulo. E-mail: pitta.fabio@gmail.com. Orcid: orcid.org/0000-0002-5460-9669

2. Cássio Arruda Boechat é Professor do Departamento de Geografia do CCHN, Universidade Federal do Espírito Santo (UFES). Email: cassio.boechat@ufes.br. Orcid: orcid.org/0000-0003-4280-6347.

3. Maria Luisa Mendonça é Doutora em Geografia Humana pela FFLCH, Universidade de são Paulo; Pesquisadora Visitante do Graduate Center da City University of New York e Coordenadora da Rede Social de Justiça e Direitos Humanos. E-mail: marialuisam222@ gmail.com. 
which characterizes itself by the expulsion of labor from the productive process mainly from the 1970 s on. After the 2001-2008 commodities price peak in the international markets and after the reversion of this cycle, we can observe the "detachment" between commodities' prices and land prices. Real Estate speculative investments reached the MATOPIBA region in the $21^{\text {st }}$. century, turning it into a privileged place for transnational investments, especially after the 2008 crisis. The low costs of farms formation due to illegal land appropriation and the rapid land prices increase in recent years fed back such increase and fostered recent transnational demand for those sorts of investment, allowing the prices to keep increasing independently in relation to commodities prices in the international markets.

Keywords: Land Grabbing. MATOPIBA. Fictitious space production. Capital crisis. Rural real estate transnational companies.

Introdução

MATOPIBA é um acrônimo a partir das iniciais dos estados brasileiros do Maranhão, Tocantins, Piauí e Bahia. Ficou assim conhecida em reportagens da mídia e projetos do governo. Academicamente falando, por sua vez, era mais utilizado o de BAMAPITO (ALVES, 2006), já que se refere ao processo histórico de chegada da soja nas áreas de chapada no Cerrado de tais estados. Em maio de 2015, porém, o governo tornou oficial a região do MATOPIBA por meio do Decreto no. 8.447, que instituiu o Plano de Desenvolvimento Agropecuário do MATOPIBA e o seu Comitê Gestor articulando os referidos estados e diversos ministérios, corroborando a existência de uma região do planejamento de Estado assim denominada e tendo seu "desenvolvimento" explicitamente atrelado à agropecuária (PITTA; MENDONÇA, 2015).

Antes mesmo de tal consolidação, a área em questão vinha sido alvo da especulação imobiliária agrícola e da expansão do agronegócio, que conta com incentivos fiscais e créditos subsidiados pelo Estado para financiar a produção de soja, milho, eucalipto, algodão e cana-de-açúcar, evidenciando um longo processo de territorialização do capital modificado recentemente pelas suas formas mais desdobradas. A possibilidade da compra de terras a preço baixo ocorre no processo de formação das fazendas, muitas vezes através da grilagem, e causa o desmatamento do Cerrado nativo. Depois de formada a fazenda para a produção de commodities, ocorre a tendência de inflação do preço da terra. A escalada do preço da terra no MATOPIBA, no século XXI, transformou-a em zona de interesse para a especulação fundiária nacional e transnacional (PITTA; CERDAS; MENDONÇA, 2018).

A expansão territorial da produção de commodities é estimulada por agentes financeiros, principalmente fundos de pensão e de investimentos transnacionais que se associam ao agronegócio no Brasil. A aparência de um capital financeiro diretamente atrelado ao capital produtivo do chamado agronegócio esconde, no entanto, um interesse na especulação imobiliária. O conhecido mecanismo de grilagem de terras é utilizado em "novas" fronteiras agrícolas para facilitar a atuação de agentes internacionais no mercado local de terras. Este processo intensifica a exploração do trabalho e a violência contra povos indígenas, quilombolas e camponeses. É por 
tais condicionamentos e consequências que relacionamos os processos aqui tratados à discussão sobre land grabbing (SAUER; BORRAS, 2016), incorporando sua dimensão mais explicitamente violenta, atrelada à expropriação (WHITE; BORAS; HALL; SCOONES; WOLFORD, 2012), mas também permitindo uma abordagem que inclua outros elementos menos explícitos de controle (PELUSO; LUND, 2011) que nos levam a pensar na dimensão especulativa do capital fictício que lhes sustenta.

Em nossas pesquisas recentes sobre a expansão de monocultivos para a produção de agrocombustíveis ${ }^{4}$ percebemos que, após a crise econômica mundial de 2008, há uma queda acentuada nos preços das commodities agrícolas no mercado internacional, com retomada de sua inflação por um curto período e uma tendência de queda destes preços a partir de 2012, o que se acentua ainda mais em 2014. Ao mesmo tempo, o preço da terra agrícola no Brasil mantém uma tendência inflacionária, o que nos levou a perceber um processo de "descolamento" entre o mercado de terras e o mercado daquelas commodities agrícolas (BOECHAT; PITTA; TOLEDO, 2017). Este fato, somado aos nossos estudos sobre empresas imobiliárias rurais que foram criadas a partir deste período (PITTA; MENDONÇA, 2015), levou-nos a apreender o processo especulativo que aprofundamos na pesquisa a ser aqui apresentada, com ênfase em seus desdobramentos no MATOPIBA (PITTA, CERDAS; MENDONÇA, 2018). Desse modo, a pergunta que motiva este artigo é quanto a se as tendências que observamos particularmente na produção de agrocombustíveis, mais localizada em lavouras do Centro-Sul do país, podem ser verificadas na produção de soja que capitaneia a recente territorialização do agronegócio nesta região particular de transição entre o Norte e Nordeste do Brasil.

No que se refere, entretanto, ao papel do capital fictício permeando tal territorialização indicamos a concepção de uma produção do espaço na qual as materialidades estão diretamente subordinadas ao seu movimento global, permitindo a sugestão de uma qualificação deste processo como, no fundo, uma produção fictícia do espaço.

Parte I: Modernização da agricultura e expulsão dos camponeses no Cerrado brasileiro a partir da segunda metade do século XX

A partir da década de 1950, teve início no Brasil um processo de modernização da agricultura, decorrente a princípio do desdobramento da industrialização nacional (levando à fabricação de tratores, implementos e insumos ditos modernos) e conduzindo posteriormente à constituição de indústrias processadoras de mercadorias agropecuárias (DELGADO, 1985). Essa integração entre agricultura e indústria, que teria levado à constituição de complexos agroindustriais (SILVA, 1982), corroboraria a consolidação posterior de uma ideologia ou consenso (DELGADO, 2012) e uma sociedade do agronegócio (HEREDIA; LEITE; PALMEIRA, 2010). Denominaremos, no decorrer deste artigo, agroindústria como sendo personificação dessa modernização. Nesse processo, foi fundamental o apoio do Estado brasileiro, que garantiu políticas de fornecimento de crédito subsidiado para o estabelecimento e reprodução da agroindús-
4. www.social.org.br 
5. “Tal denominação foi empregada pelo Banco Mundial para se referir aos novos cultivos baseados em sementes de alto rendimento desenvolvidas pelo agrônomo norte-americano Norman Borlag, e passou a ser comumente utilizada para se referir ao conjunto de políticas e estratégias adotadas para acelerar a imposição da lógica industrial capitalista no campo [...].Estivesse no Hemisfério Norte ou Sul, a orientação de práticas agrícolas da Revolução Verde era a mesma: uso intensivo do solo irrigação, rotação de curta duração, aplicação de fertilizantes inorgânicos, controle químico de pragas, fungos e ervas, e uso regular de maquinários. Os fabricantes por detrás dos pacotes tecnológicos enfatizavam que os resultados econômicos da produção agropecuária estavam diretamente atrelados ao uso combinado de tais mercadorias [...]" (CAMARGO, 2010, p. 19-21). tria, assim como isenções fiscais, administração de preços e fomento da ocupação por empresas e fazendeiros de terras devolutas (antes ocupadas por camponeses, indígenas e quilombolas), além de promover uma ampla reformulação normativa e de conduzir uma política de erradicação de cafezais a fomentar uma diversificação da agropecuária com expulsão de agregados e trabalhadores residentes (STOLCKE, 1986).

Diversas relações sociais de produção particulares existentes no campo foram sendo transformadas. Formas de trabalho como as do colono da cafeicultura, do morador da produção canavieira nordestina, dos vaqueiros da pecuária dos sertões, entre outras, nas quais o trabalhador vivia dentro das propriedades e tinha acesso parcial e mediado aos meios de produção ou ao produto de seu trabalho, foram sendo questionadas tanto pelas novas legislações (Estatuto do Trabalhador Rural, de 1963, e Estatuto da Terra, de 1964, por exemplo) como pelas novas formas de se produzir que, além de permitirem a comparação do trabalho manual com o potencializado pelos novos meios de produção industrializados, permitiam introduzir novos cultivos e mesmo reavaliar as terras antes cedidas como potencialmente geradoras de rendimentos (BOECHAT; LEITE; TOLEDO 2017).

Cabe ressaltar que um fator determinante para tal papel do Estado brasileiro foi a disponibilidade de capitais do sistema financeiro do centro do capitalismo, principalmente dos EUA e da Europa. Essa disponibilidade permitiu, por meio do endividamento externo do Estado brasileiro, a concessão de créditos subsidiados, atrelados à compra de maquinário com excesso de oferta, necessitando serem vendidos para a acumulação das empresas que os produziram, provenientes também do centro do capitalismo. Ou seja, a dinâmica de crise de "superacumulação de capital" (OLIVEIRA, 1977; HARVEY, 2005) e expansão capitalista contribuiu de maneira decisiva com a formação da agroindústria brasileira (BOECHAT, 2014; PITTA, 2016).

A partir dos governos da ditadura militar (1964 - 1985), a modernização do campo se transformou em um dos carros chefe das políticas públicas. Desde a criação do Sistema Nacional de Crédito Rural (SNCR, em 1965), passando pelo I Plano Nacional de Desenvolvimento (PND, 1968 - 1973), correspondente ao que ficou conhecido como "milagre econômico brasileiro", e pelo II PND (1975 - 1979), aprofundaram-se as contradições do modelo de desenvolvimento adotado, explicitadas também com a ajuda de uma conjuntura internacional adversa agravada após a crise do petróleo de 1973, levando à "explosão" no Brasil da dívida pública e privada internacional (DAVIDOFF, 1984), da inflação, da superexploração do trabalho (tanto urbana quanto rural) e das expropriações no campo.

A constituição das agroindústrias no Brasil para a produção de commodities (atualmente as principais são soja, milho, açúcar, algodão e suco de laranja concentrado e congelado), tendo a exportação como seu principal sentido, completou a implantação da chamada Revolução Verde 5 . O pacote tecnológico adotado, combinando o uso de insumos químicos industrializados e maquinários para produção, colheita e beneficiamento, implicou no aumento do capital constante investido necessário para se iniciar uma produção agrícola e na dispensa relativa de força de trabalho 
para realizar tal produção. Uma vez que boa parte dessa força de trabalho, até os anos 1960, encontrava-se no interior das propriedades, esta mudança na composição orgânica dos capitais contribuiu para a sua acelerada expulsão. Desse modo, o assalariamento precário daí resultante seguiria enfrentando a mesma dinâmica, agravando nas décadas seguintes o nível e as condições de emprego agrícola e conduzindo a uma dispensa absoluta de força de trabalho.

Para termos um exemplo, a produção de cana-de-açúcar, entre os anos 1960 até 1980, mecanizou parcialmente o plantio e amplamente os tratos culturais, mas manteve a colheita manual. Se na década de 1960 se utilizava aproximadamente dois milhões de trabalhadores no campo no estado de São Paulo, desde então o maior produtor do país, ao final dos anos 1980, tendo a produção de cana se tornado hegemônica no estado e se utilizando do trabalho dos bóias-frias principalmente para o corte, o número de trabalhadores empregados era de quinhentos mil (PITTA, 2011). Atualmente, após o boom dos preços das commodities da primeira década do século XXI e da consequente mecanização quase completa do corte (PITTA, 2016), o número de trabalhadores caiu para menos de noventa mil.

O mesmo aconteceu com a produção de soja, em sua expansão dos estados do Paraná e do Rio Grande do Sul para o estado do Mato Grosso entre as décadas de 1970 e 1980 (BERNARDES, 2007). Atualmente, o trabalho manual na produção de soja se reduz a alguns momentos do plantio direto e da manutenção da produção, aí muitas vezes por meio de trabalho análogo à escravidão, por exemplo, para a catação manual de ervas daninhas e para a catação manual de pedras, necessária para preservar as colhedeiras de soja.

Por outro lado, a expansão da fronteira agrícola e a privatização de terras de uso comum potencializaram a tensão e os conflitos no campo, corroborando processos de expropriação (LEITE, 2015). Se, de um lado, a "marcha para o Oeste" compunha a integração nacional, desde os anos 1940, ela adquiriria novos significados com a "militarização da questão agrária" atrelada à Revolução Verde. A possibilidade de acesso à terra na fronteira agrícola passaria a ser condicionada pelo planejamento regional e pela ascensão de um novo modelo produtivo.

Desse modo, para entendermos as particularidades da expansão da soja no MATOPIBA, primeiramente neste período de "simulação" da acumulação capitalista por meio de mecanismos financeiros de rolagem de dívidas, precisamos nos remeter a dois importantes programas relacionados ao II Plano Nacional de Desenvolvimento (PND): o POLOCENTRO (Programa de Desenvolvimento Agrícola do Cerrado), vigente de 1975 a 1979; e, principalmente (por isso a opção por abordarmos este adiante), o PRODECER (Programa Nipo-Brasileiro de Desenvolvimento Agrícola da Região dos Cerrados), que vigorou de 1979 até 2001 com diversas fases (SANTOS, 2016).

A estratégia econômica adotada no II PND foi explicitamente a de promover a constituição de conglomerados financeiros, visando uma centralização de capitais que permitisse que empresas nacionais pudessem competir na nova ordem internacional, cabendo uma associação com o 
6. “É de prever-se que o programa de colonos e pequenos produtores, pela densidade demográfica da região e pelas suas características físico-climáticas terá mais ênfase no Nordeste e em certas áreas, limitadas do Centro-Oeste e da Amazônia. Na implantação dos programas de empresas, evitar-se-ão distorções, como a de atribuir sentido de feudos a tais explorações, limitando-

-se a concessão de terras ao estritamente necessário à atividade produtiva. Também se procurará impedir a tentativa de usar a terra principalmente como investimento fundiário, controlando-se a implantação efetiva dos projetos, em prazos bem definidos" (BRASIL, 1975, p.

61). De algum modo, esta preocupação

com a colonização e o uso produtivo

da terra deriva dos princípios gerais emanados desde a Lei no. 601, de 1850, a chamada Lei de Terras. Nela, pode-se ver uma relação entre a constituição de um mercado de terras (art. 1), mediando

a incorporação na forma mercadoria

de formas pretéritas de acesso à terra (por sesmarias ou por posses livres) por meio da privatização de terras devolutas com o intuito de se fazer um fundo para se criar uma política de imigração de trabalhadores livres (art. 18). Tratava-

-se, portanto, de evitar a dispersão de trabalhadores ao se apossarem de terras "livres", tornando-as terras do

Estado, que deveria direcioná-las ao mercado, promovendo o suprimento de trabalhadores às empresas (MARTINS

2000). Tal comercialização de terras devolutas, como se sabe, não chegou a ocorrer como o planejado, havendo um controle coronelista sobre o seu acesso principalmente pelo controle de cartórios de registros (o que, é claro, incluía o monopólio sobre a manipulação de escrituras, isto é a grilagem de terras), de maneira que a região se "fechava" à livre circulação da força de trabalho

e do capital, devendo a mesma ser mediada pelo poder dos coronéis. Neste sentido, a "integração nacional" pode ser compreendida como longo processo de ruptura da armature regional (GOLDENSTEIN; SEABRA, 1982), permitindo a mobilização do trabalho e 0 acesso aos meios de produção (até então regionalmente monopolizados) por novos grupos econômicos, também através do

planejamento regional e seus "blocos integrados de investimentos" (OLIVEIRA, 2008). Certamente, há uma inflexão decisiva no sentido de uma integração do mercado de terras por meio do processo de integração nacional

7. No Paraná, em Mato Grosso do Sul e no Mato Grosso, é de suma importância ressaltarmos aqui, foi aprofundado um capital estrangeiro no provimento de tecnologias avançadas e investimentos (BRASIL, 1975, p. 47-55). No entanto, ela se articulava à política de integração nacional que incluía a ocupação do "universo brasileiro" (BRASIL, 1975, p. 56). A ocupação da hinterlândia era concebida aí como política populacional que promoveria a criação de novos empregos na fronteira agrícola, mas sobretudo como fonte de produção de alimentos e matérias-primas, por meio de "blocos integrados de investimentos em polos, distritos agroindustriais ou outras formas, permitindo a adoção de prioridades nítidas e controle dos resultados fisicamente, por área" (BRASIL, 1975, p. 60). A política de colonização se somava à de promoção de grandes investimentos, sempre com a preocupação, ao menos em tese, de evitar uma "regressão econômica" (FURTADO, 2000)

Assim, a política de modernização da agricultura brasileira, no caso da produção de soja, transformou a ocupação do Cerrado, a partir dos anos 1970, e aprofundou processos de expropriação, tanto no que diz respeito à expulsão direta de posseiros, agregados das fazendas pecuaristas, como também de indígenas e pequenos produtores que viviam naquela região ${ }^{7}$, quanto em relação à concentração e centralização do capital (Marx, 1984, Cap. XXIII: A lei geral da acumulação capitalista) dos diferentes momentos da produção e processamento das agroindústrias nas mãos da indústria à montante e à jusante da produção e das tradings (MENDONÇA, 2013).

A forte expansão sobre o Cerrado do Mato Grosso do Sul e do Mato Grosso, a partir dos anos 1970, conduziu sojicultores menos produtivos a venderem suas terras e produções, a partir de uma dinâmica de crise de seus capitais e a migrarem para locais de terras mais baratas e ainda não ocupadas pela produção agroindustrializada, promovendo uma expansão da fronteira da soja tanto para a Floresta Amazônica, como para o Cerrado do Nordeste, incluído aí o MATOPIBA. Ao mesmo tempo, grandes produtores também passaram a expandir suas produções para tais regiões de terras baratas passíveis de subirem de preço, justamente em razão dos incentivos para tal movimento.

A partir de incentivos fiscais e de produção de uma infraestrutura locais, mas, principalmente, incentivos à ocupação de terras a preços módicos, por meio do fomento dos estados e de grilagens de terras, constituiu-se um mecanismo de expansão e de ocupação que tinha na terra importante elemento da acumulação no que diz respeito à chegada da fronteira com soja: realizava-se a expropriação para formar uma fazenda de gado, aguardar a produção de soja chegar e vender a terra para tanto ${ }^{8}$. A terra neste momento se constituía, então, como uma mercadoria e se inseria em um mercado nacional de terras, modificado pelas políticas de "integração nacional". Após a ocupação do Cerrado do Centro-Oeste do país, tal expansão, já nos anos 1980, atingiu a Bahia e a partir dos anos 1990, chegou ao Maranhão e Piauí. Vale destacar que, no caso do Maranhão, a grilagem de áreas de chapada na cidade de Balsas, muito bem descrita na tese de doutorado de Roberto Miranda (2011), foi o marco inicial da chegada dos processos de modernização agrícola àquela região. Em 2015, a Rede Social de Justiça e Direitos Humanos lançou o relatório A empresa Radar S/A e a especulação com terras no Brasil (PITTA; MENDON- 
ÇA, 2015), na qual apresentava o interesse de transnacionais imobiliárias agrícolas em especular com terras como ativos financeiros, justamente nesta chapada em Balsas, o que lança luz ao intuito desta parte do artigo de articular os mecanismos mais recentes de acesso ao capital fictício com o processo pretérito de territorialização do capital. Assim, após a chegada da produção de soja, sua expansão dependia de novo acesso ao endividamento e a mecanismos financeiros de acumulação, o que retroalimentava sua promessa de expansão, a fim de acessar novos financiamentos, dando continuidade ao seu processo de ocupação territorial. Isto fica bem refletido no debate feito na Câmara dos Deputados, em inícios dos anos 1980, quando a instauração do PRODECER era alvo de críticas e oposição:

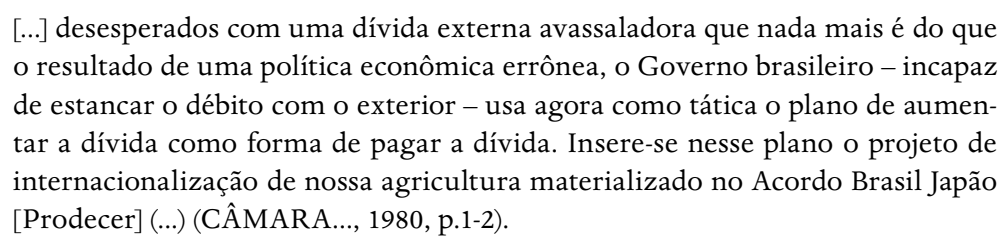

[...] desesperados com uma dívida externa avassaladora que nada mais é do que o resultado de uma política econômica errônea, o Governo brasileiro - incapaz de estancar o débito com o exterior - usa agora como tática o plano de aumentar a dívida como forma de pagar a dívida. Insere-se nesse plano o projeto de internacionalização de nossa agricultura materializado no Acordo Brasil Japão [Prodecer] (...) (CÂMARA..., 1980, p.1-2).

A partir da necessidade de intermediação da "simulação" financeira para a produção de mercadorias, podemos concluir para tal momento que tanto a expropriação de indígenas e do campesinato como a superexploração do trabalho assalariado não eram, de meados dos anos 1970 em diante (tanto no Brasil, como em termos mundiais), suficientes para a acumulação capitalista ocorrer (SCHOLZ, 2016), apesar de continuarem existindo como consequência mesma de tal processo de modernização.

Desse modo, a modernização da agricultura, necessária em termos capitalistas como tentativa do Brasil em se aproximar dos níveis de produtividade dos países centrais, teve como consequência, desde os anos 1960, a expropriação reiterada de indígenas e camponeses, a eliminação gradativa de formas de parcerias agrícolas e a expulsão da força de trabalho assalariado do processo produtivo, dificultando cada vez mais a reprodução social daqueles camponeses expropriados, antigos parceiros ou migrantes volantes que passavam a ter que vender sua força de trabalho para sobreviver. Tal movimento do capitalismo vale tanto para o campo como para a cidade e é a explicação para o "desemprego estrutural" que hoje é uma realidade mundial (KURZ, 1999, SASSEN, 2016 e OLIVEIRA, 2016), assim como da miséria e da pobreza como suas consequências diretas. A expulsão do trabalho do processo produtivo de mercadorias se intensificou em razão da terceira revolução industrial, caracterizada pela microeletrônica e sua consequente robotização e automação das indústrias, tanto urbanas quanto das agroindústrias (KURZ, 1999):

\footnotetext{
[...] Mas já que a abertura forçada ao mercado mundial e a exigência de uma produtividade elevada impediam uma industrialização recuperadora completa e extensa, a acumulação primitiva não chegou a terminar sua obra. Ficou parada na metade do caminho, isto é, depois de desarraigar as massas, deixou de integrá-las na moderna máquina de exploração em empresas (KURZ, 1999, p. 181).
}

Por isso, a socióloga Saskia Sassen vem usando o termo "expulsões" (SASSEN, 2016) para denominar a característica fundamental das expropriações a nível mundial na atualidade. Além de relacioná-las aos movimentos especulativos do capital financeiro como sentido da acumulação capitalista mundializada, ela destaca que o capitalismo atual expulsa tra- processo de expropriação dos Guarani (Kaiowá, M'byá, Ñandeva e Avá) das terras que ainda ocupavam. Muitos foram apresados e aldeados em ínfimas parcelas de terra localizadas nas periferias das cidades do interior de tais estados, aldeamentos estes criados na primeira metade do século XX pelo órgão estatal responsável pela política indigenista, o SPI (Serviço de Proteção ao Î́ndio). Tais aldeamentos se caracterizam pela reduzida extensão e pela insuficiência para a reprodução social dos Guarani, que acabam tendo que se vender como força de trabalho superexplorada nas produções de commodities das agroindústrias do campo brasileiro. Sobre a expropriação dos Guarani ver os seguintes relatórios de pesquisa da Rede Social de Justiça e Direitos Humanos: A Agroindústria canavieira e a crise econômica mundial (XAVIER, NAVARRO, PITTA; MENDONÇA, 2012) e Empresas Transnacionais e Produção de Agrocombustíveis no Brasil (XAVIER, NAVARRO, PITTA; MENDONÇA, 2014)

8. Para maior compreensão de tal processo no MATOPIBA, mas também especificamente para o caso do Piauí, ver Alves, 2006. 
9. 0 termo "simulado" aqui se refere ao conceito de "capital fictício" de Marx (1985), que o utilizou para se remeter a uma acumulação crítica, feita por meio de dinheiro que se transforma em mais-dinheiro sem exploração do trabalho suficiente na forma de mais-valia para acumulação de capital. Utilizaremos tal termo no resto do presente relatório. balho do processo produtivo e forma uma massa de excluídos a viverem em parcelas de terra insuficientes para sua reprodução e sobrevivência (p. ex., a situação de indígenas e camponeses no MATOPIBA), dentre outras condições de precariedade extrema. Podemos encontrar sintomas de tal análise nos presídios relacionados ao processo global de encarceramento em massa, nos campos de concentração e de refugiados e nas periferias e favelas das metrópoles globais (SASSEN, 2016). Diz ela sobre o atual momento do capitalismo mundial e o conceito de "expulsões":

\footnotetext{
Em sua forma mais extrema, pode levar à miséria e à exclusão de cada vez mais pessoas, que deixam de ter valor como produtores e consumidores [...]. Essas tendências não são anômalas, nem são resultado de uma crise. São parte do atual aprofundamento sistêmico das relações capitalistas. [...] A população - enquanto trabalhadores e consumidores - tem desempenhado um papel cada vez menor nos lucros de muitos setores econômicos. Por exemplo, da perspectiva do capitalismo atual, os recursos naturais de grande parte da África, América Latina e da Ásia Central são mais importantes do que as pessoas que vivem naquelas terras, na condição de trabalhadores e consumidores (SASSEN, 2016, p. 19).
}

Assim, poderíamos dizer que o mercado de trabalho, a partir da terceira revolução industrial e da modernização da agricultura, significou, para a população trabalhadora, entre camponeses e assalariados, a necessidade de aceitar as piores condições de trabalho existentes, já que a concorrência por estes rebaixava e precarizava as próprias condições de trabalho. Desta forma, superexploração do trabalhador, condições de trabalho análogo à escravidão, desemprego e expropriação da terra ou do trabalho do campesinato não são fruto do atraso, mas sim da modernização endividada brasileira. Para a empresa capitalista, por sua vez, aqui no caso particular das agroindústrias, com cada vez menor quantidade de trabalho para ser explorado e transformado em seus lucros, fica cada vez mais difícil alcançá-los, a não ser que sejam "simulados" por mecanismos financeiros, como utilização de créditos subsidiados, isenção fiscal, política de preços acima dos custos das empresas e anistia das dívidas já subsidiadas (THOMAZ JR., 2002), justamente o quadro que marcou o primeiro e o segundo PNDs.

A promessa de expansão de uma produção agroindustrial por meio da rolagem da dívida externa brasileira moveu processos de expropriação e grilagem também na área do MATOPIBA, já nos anos 1970 e 1980, alcançando os anos 1990. A própria promessa de implantação de infraestrutura, como ferrovias e estradas, que permitissem a apropriação de Renda Diferencial I (MARX, 1985) - aquela referente a diferenças de produtividade natural do solo e também de localização do mesmo, reduzindo custo com fretes, por exemplo -, impulsionou os processos de expropriação e grilagem, na região em questão.

Conforme indicam as pesquisas de Alves (2006 e 2015), as áreas altas e planas das chapadas eram as áreas prioritárias a serem ocupadas. Ali as produções podiam acessar um regime pluviométrico adequado, além de serem justamente os locais de cabeceira / nascentes dos rios do Cerrado na região. As chapadas eram também adequadas à mecanização (plantio, tratos culturais e colheita), já que são planas, permitindo inclusive a irrigação por meio de pivôs centrais, em alguns casos. Como estas terras eram antes utilizadas de forma comum, tanto por camponeses como por 
produtores pecuaristas, mas não frequentemente eram lugar de moradia para as populações locais, em diversas situações se veiculou o discurso de que eram desocupadas e desabitadas. Porém, como é evidente, as chapadas eram de suma importância para a reprodução das populações locais, já que dali coletavam frutas e medicamentos, caçavam e soltavam o gado em certos períodos do ano, conforme a temperatura e as estações de chuva e seca. A ocupação (na maioria das vezes ilegal) das chapadas pela expansão, sobretudo, da produção de soja inviabilizou o uso das mesmas por parte daquelas populações locais e "fechou" a fronteira para que continuassem se deslocando conforme a produção agroindustrial avançava. Tais populações foram expropriadas das chapadas. Diversas foram as comunidades que deixaram de existir, principalmente aquelas que tinham nesses seus locais de moradia. Seus membros migraram definitivamente para as periferias das cidades, passaram a habitar as favelas dos grandes centros urbanos e passaram a se vender como força de trabalho assalariado, quando arrumavam emprego (ALVES, 2006).

Por sua vez, as comunidades que habitavam os chamados baixões, muitas vezes, mantiveram a posse de suas terras. Em algumas situações também foram expropriadas dessas áreas e acabaram por migrar, assim como as comunidades anteriormente destacadas. As que mantiveram seu espaço de moradia, o fizeram sobre áreas a partir de então insuficientes para poderem se reproduzir, já que as chapadas não se encontravam mais disponíveis para o uso comum. Os membros destas comunidades habitantes dos baixões passaram a integrar o mercado de força de trabalho como volantes migrantes. Nos períodos de safra agrícola, por exemplo, migravam para áreas de produção agroindustrial contratantes de trabalho assalariado, sob míseras condições de trabalho, quando o encontravam, como é o caso da produção de cana-de-açúcar no Centro-Sul do Brasil e do trabalho do cortador de cana, bóia-fria (ALVES, 2015).

O caso da expropriação de pequenos produtores nas áreas de chapada do chamado Gerais de Balsas, no sul do Maranhão, do final dos anos 1980 e início dos anos 1990, é bastante representativo do processo que viemos descrevendo até aqui, de implantação da agroindústria da soja na área do MATOPIBA. Em tese de doutorado, Roberto Miranda (2011) recuperou o histórico de grilagem ${ }^{10}$ violenta de terras nesta região, além do desmatamento, formação das fazendas e sua venda para os sojicultores que eram provenientes do Centro-Sul do Brasil. A promessa de chegada da produção de soja fomenta, especulativamente, o início da grilagem das terras nos Gerais de Balsas/MA. Já nos anos 1990, a SLC (Schneider Logemann Company) Agrícola S/A se implantou na região dos Gerais de Balsas, no Maranhão, região que foi quase em sua totalidade ocupada no século XXI, por exemplo. A SLC Land Co., criada em 2012, braço imobiliário da SLC Agrícola S/A, em sociedade com o fundo de investimentos inglês Valiance Capital, possui parte daquelas fazendas griladas nos anos 1990. A Radar Propriedades Agrícolas, criada em 2008 , sociedade entre a Cosan S/A e o fundo de pensão TIAA-CREF (Teachers Insurance and Annuity Association of America - College Retirement Equities Fund), também possui terras nesta região dos Gerais de Balsas, que tiveram as fazendas formadas entre os finais dos anos 1980 e a década de 1990 (PIT-
10. 0 esquema de grilagem de terras diz respeito a uma falsificação de titulação fundiária com a intenção de simular a legitimidade de uma apropriação ilegal de terras. 0 termo se remete à prática de guardar os documentos falsificados com grilos para que a sujeira dos insetos fizesse que os documentos falsos parecessem antigos e passassem por legítimos. 
TA; MENDONÇA, 2015). Falaremos destas transnacionais imobiliárias agrícolas mais detidamente adiante, no presente artigo, ambas possuem mais de uma fazenda no MATOPIBA.

Na primeira metade dos anos 1990, após a moratória da dívida externa brasileira de 1986 e o Plano Real, os créditos subsidiados por parte do Estado para a industrialização da agricultura secaram, diversas empresas quebraram, o que acarretou inclusive em diminuição dos preços da terra agrícola no país (DELGADO, 2012). Porém, já na segunda metade dos anos 1990, o BNDES retomou os créditos para a produção agrícola, o que deu novo impulso à ocupação de terras no Cerrado brasileiro, impulso que foi retroalimentado de maneira profunda pelo ciclo de alta dos preços das commodities nos mercados mundiais de futuros (KURTZ, 2011; Delgado, 2012), ciclo que se iniciou em 2001/2002 com queda de preços após a crise econômica mundial de 2008/2009, e uma nova queda, ainda mais brusca, nas safras de 2012/2013. Nesta nova e recente fase de expansão territorial da produção de soja, a ocupação do Cerrado do MATOPIBA foi ainda mais profunda, atingiu novamente a Bahia e o Maranhão, mas terminou por alcançar definitivamente o sul do Piauí e do Tocantins, como veremos a partir do próximo item.

\section{Parte II - A expansão do agronegócio na região do MATOPIBA}

como "última fronteira" na conquista do Cerrado pelas

agroindústrias no século XXI

A partir do final dos anos 1980 e início dos anos 1990, o sistema financeiro internacional passou por mudanças profundas no que diz respeito à sua capacidade de criação de dinheiro, ou seja, realização de dinheiro que se torna mais dinheiro sem explorar trabalho suficiente para fazê-lo. Após a crise das dívidas da América Latina e a moratória de países como o México (1983) e o Brasil (1986), o sistema financeiro desenvolveu mecanismos de securitização de dívidas e de negociação de preços de ativos financeiros (os chamados derivativos) em mercados secundários (XAVIER; PITTA; MENDONÇA, 2012), sendo ambos capazes de ampliar a liquidez dos mercados, aumentar a alavancagem das empresas em geral e, aqui a consequência mais importante, aprofundar a dependência entre produção de mercadorias e financeirização da economia.

Desta forma, inaugurou-se um circuito de financiamento que alavancou os recursos oferecidos, via mercado de capitais, para os tomadores de empréstimos em geral. Este circuito inicia-se com a geração ou "originação" de ativos pelo mercado de capitais, que também se encarrega de promover a securitização e a negociação, com a qual são obtidos novos recursos, posteriormente utilizados para gerar novos ativos, realimentando o circuito. Portanto, a chamada revolução tecnológica, simultaneamente, diminuiu a vantagem competitiva dos bancos na atividade de empréstimos e deu forte impulso ao mercado de capitais. Por último, o crescimento dos investidores institucionais, em especial os Fundos de Pensão, constitui outra força competitiva atuando no mercado antes restrito aos bancos. A origem deste tipo de fundo guarda relação com os processos de privatização dos sistemas previdenciários de vários países, assim como o desenvolvimento da indústria de previdência complementar. Vale mencionar que a reação dos bancos ao acirramento da competição também teve efeito expansivo sobre o mercado de capitais. Vide a diversificação rumo as [sic] atividades fora de balanço (off-balance sheet), principalmente no mercado de derivativos (SILVA, 2007, p. 8 e 9). 
No excerto acima importa destacarmos enfaticamente o que o autor caracterizou como "realimentação do circuito". A securitização das dívidas significou a possibilidade de as instituições financeiras repassarem o risco de crédito para uma enorme diversidade de investidores, já que passaram a vender no mercado de capitais diversos tipos de dívidas, agora na figura do ativo financeiro. Além disso, a possibilidade de negociação dos preços de tais ativos nos mercados secundários de derivativos - ou seja, mercados de capitais capazes de negociar preços de títulos ou pacotes de dívidas; taxas de juros, câmbio, seguros de créditos; assim como preços futuros de commodities - aumentou exponencialmente a liquidez destes mercados e a procura por parte de capitais financeiros superacumulados por tais tipos de investimentos. Este processo, concluindo, passou a proporcionar a inflação dos preços dos ativos financeiros em termos mundiais e retroalimentou a criação de novos ativos a serem negociados (HUDSON, 2012). A "simulação" financeira dos lucros das empresas, inclusive daquelas produtoras de mercadorias deixou de ocorrer como rolagem de endividamento para estar assentada na inflação de ativos financeiros.

Do início dos anos 1980 até por volta da crise mundial de 1998 (BRENNER, 2003), que envolveu os Tigres Asiáticos, a Rússia e promoveu a maxidesvalorização do Real em 1999, a economia brasileira apresentou índices módicos de acumulação. Porém, após tal momento, o Estado, a fim de compensar os déficits comerciais gerados pela fuga de capitais relacionada à crise cambial de 1998, passou a fomentar, novamente por meio de créditos subsidiados, a agroindústria exportadora (DELGADO, 2012). Se, em meados dos anos 1990, a fronteira agrícola com soja já atingira a Bahia e o Maranhão, foi a partir do fim da década de 1990 e início dos anos 2000 que a mesma chegou de maneira mais aprofundada no Piauí e no Tocantins.
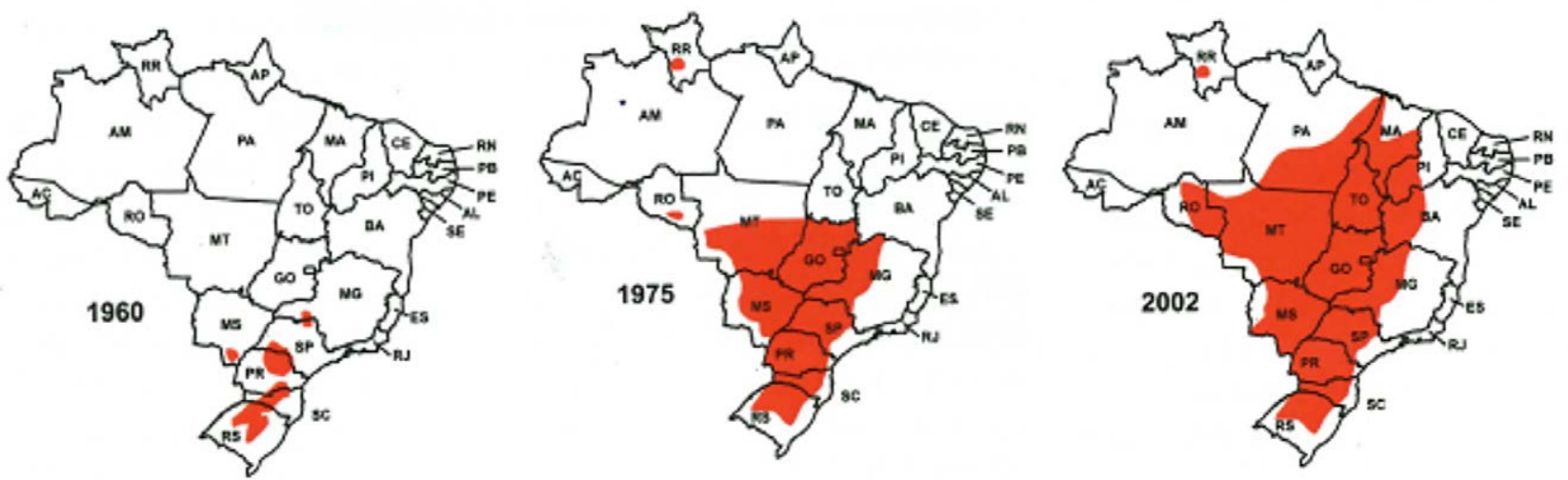

Delgado (2012) apresenta de maneira explícita como o chamado boom dos preços das commodities, a partir dos anos 2001/2002, retroalimentou, por sua vez, a expansão das agroindústrias no Brasil, expansão esta retomada pelo fomento do segundo governo de Fernando Henrique Cardoso (1999-2003):

Esse esforço de relançamento, forçado pelas circunstâncias cambiais de 1999, encontrará um comércio mundial muito receptivo na década de 2000 para meia dúzia de commodities em rápida expansão nos ramos de feedgrains (soja e milho), açúcar-álcool, carnes (bovina e de aves) e celulose de madeira, que juntamente com os produtos minerais crescerão fortemente e passarão a dominar a pauta de exportações brasileiras no período 2000 - 2010 (DELGADO, 2012, p. 95).
Figura 1 - Expansão da soja no Brasil, 1960-2002.

Fonte: JICA, 2017. 
Importa retomarmos aqui a lógica de inflação de ativos financeiros descrita anteriormente e que passou a dominar os movimentos do capitalismo, a partir de meados dos anos 1990, para entendermos a exponencial expansão das agroindústrias em geral no Brasil, a partir de tal momento. Foi a inflação dos preços das ações de empresas de tecnologia, na bolsa estadunidense Nasdaq, que fomentou a acumulação capitalista dos EUA na década de 1990 e do resto da economia mundial, a partir desta economia central. A lógica da inflação dos ativos financeiros, por sua vez, está relacionada a uma subida especulativa do preço de determinado ativo, subida esta que atrai novos investidores em busca de rendimentos, mas que acaba por levar a uma deflação brusca (como estouro de uma bolha financeira) de tal ativo e levar à bancarrota empresas, inclusive produtivas, relacionadas ao ativo em questão. A partir de 2001 os preços das empresas de tecnologia despencaram, com a quebra da Nasdaq (BRENNER, 2003), e capitais financeiros ociosos passaram a buscar se valorizar em novos ativos que poderiam rápida e profundamente serem inflacionados. Os dois principais foram o setor imobiliário estadunidense e europeu e as commodities (DELGADO, 2012; KURZ, 2011), com seus preços inflados negociados nos mercados de futuros (derivativos de commodities, HUDSON, 2012).

A crise do mercado de hipotecas imobiliárias nos EUA, partir de 2007/2008, como estouro de outra bolha de ativos (HUDSON, 2012), levou à bancarrota bancos (Lehman Brothers), seguradoras (AIG), empresas (GM). No Brasil, faliu a Sadia, por exemplo, assim como diversas usinas de açúcar e etanol (XAVIER; PITTA; MENDONÇA, 2012), mas também em países (como a Grécia e a Islândia), ou seja, impactou a economia capitalista mundial como um todo, em razão da interdependência entre suas esferas financeira e produtiva. Cabe ressaltar que, conforme nossa perspectiva aqui apresentada, a atual crise econômica brasileira está imanentemente relacionada a tal crise do capitalismo mundial.

A retroalimentação que a inflação de ativos moveu ao entrelaçar os mercados de capitais com os setores produtivos da economia capitalista ficou explícita na crise imobiliária dos EUA. Investimentos securitizados, tanto para construção de imóveis como para crédito pessoal para aquisição dos mesmos, moveram a subida dos preços dos imóveis. Seus proprietários, além disso, podiam hipotecar seus imóveis com preços em ascensão e consumir, o que impulsionou o aquecimento da economia estadunidense, inflacionando-a, inclusive, na primeira década do século XXI (HARVEY, 2011). Com as hipotecas, os proprietários podiam até mesmo comprar novos imóveis, transformando-os em uma "máquina de sacar dinheiro" (HUDSON, 2012), retroalimentando a subida de seus preços, o que fez com que tal processo parecesse não ter fim.

Por outro lado, o desemprego estrutural da economia capitalista em termos mundiais, em razão da alta mecanização dos processos produtivos, não conduz ao aumento do trabalho (produtivo), nem promove o aumento dos salários de forma suficientes a pagar as dívidas adquiridas por meio da inflação de ativos, o que acarreta, consequentemente, uma deflação dos preços do ativo em questão quando da incapacidade da expansão financeira em retroalimentar o momento altista de uma de- 
terminada bolha especulativa. Na verdade, a economia capitalista teria se transformado em um cassino de jogadores com os preços de ativos nos mercados secundários que assim passaram a influenciar a produção transnacional de mercadorias a nível mundial (KURZ, 1995; PITTA, 2016; SASSEN, 2016).

Os exorbitantes montantes de investimento financeiro no setor imobiliário nos EUA e Europa também ocorreram no que diz respeito aos mercados de commodities em geral e consequentemente também ao de terras agrícolas. Os fundos de pensão, os fundos mútuos e os chamados hedge funds, como enormes poupanças em busca de valorização, também moveram a subida especulativa dos preços commodities negociáveis nos mercados de futuros, nos quais na realidade se negocia uma promessa de preço de uma transação futura (PITTA, 2016).

Dado que a partir destes preços futuros é possível que produtores de commodities, tradings e indústrias processadoras adquiram financiamento sobre uma promessa de produção a ser entregue no futuro, em espécie, ficamos diante de um cenário que também se retroalimenta enquanto a tendência de alta dos preços nestes mercados se mantém. Em certo sentido, poder-se-ia dizer que quanto maior sua capacidade de produzir uma commodity (que é o ativo financeiro dos produtores e tradings de commodities), maior sua capacidade de adquirir adiantamentos sobre uma promessa de produção futura. Quando as grandes empresas produtoras de commodities passam a abrir seus capitais em bolsas de valores, adicionando aí suas ações também como ativos financeiros, a possibilidade de retroalimentação dos processos de inflação dos preços dos ativos financeiros se amplia exponencialmente (HUDSON, 2012), como é o caso de empresas como SLC Agrícola S/A (produtora de soja) e Cosan S/A (produtora de cana, açúcar, etanol e energia elétrica a partir da queima do bagaço da cana). A terra como outro ativo e o banco de terras dessas empresas também são utilizados como critério para a capacidade de crescimento de uma empresa e a inflação do preço da terra interessa para a lógica de "simulação" financeira dos lucros das empresas, conforme o cassino do capitalismo mundial atual (PITTA, 2016).

Importa aqui destacarmos, consequentemente com o que foi exposto até aqui, que a passagem da "simulação" da acumulação capitalista de rolagem das dívidas para a inflação dos ativos por meio do mercado de capitais (financeiro) não deixa de se relacionar com o momento de produção de mercadorias, mas, pelo contrário, passa a tratar toda e qualquer mercadoria como ativo financeiro determinando qual deverá ser produzida e qual não o será a partir da lógica especulativa das bolhas financeiras. Isso vale para a produção de açúcar, soja, minério de ferro, petróleo e inclusive para terra (SASSEN, 2016, p. 100), o que alcançaremos adiante, como ponto de chegada do presente texto. Em relação à terra como ativo financeiro, é após a crise de 2008 que investidores transnacionais passam a focá-la para seus investimentos, dada a alta de seus preços nos anos imediatamente anteriores, é isso que move a retroalimentação da alta de seu preço, assim como a criação de empresas especializadas neste tipo de negócio (PITTA; MENDONÇA, 2015; BOECHAT; PITTA; TOLEDO, 2017). 
Gráfico 1 • Índice de Preços de Commodities Agrícolas Deflacionado pela Inflação Norte-Americana

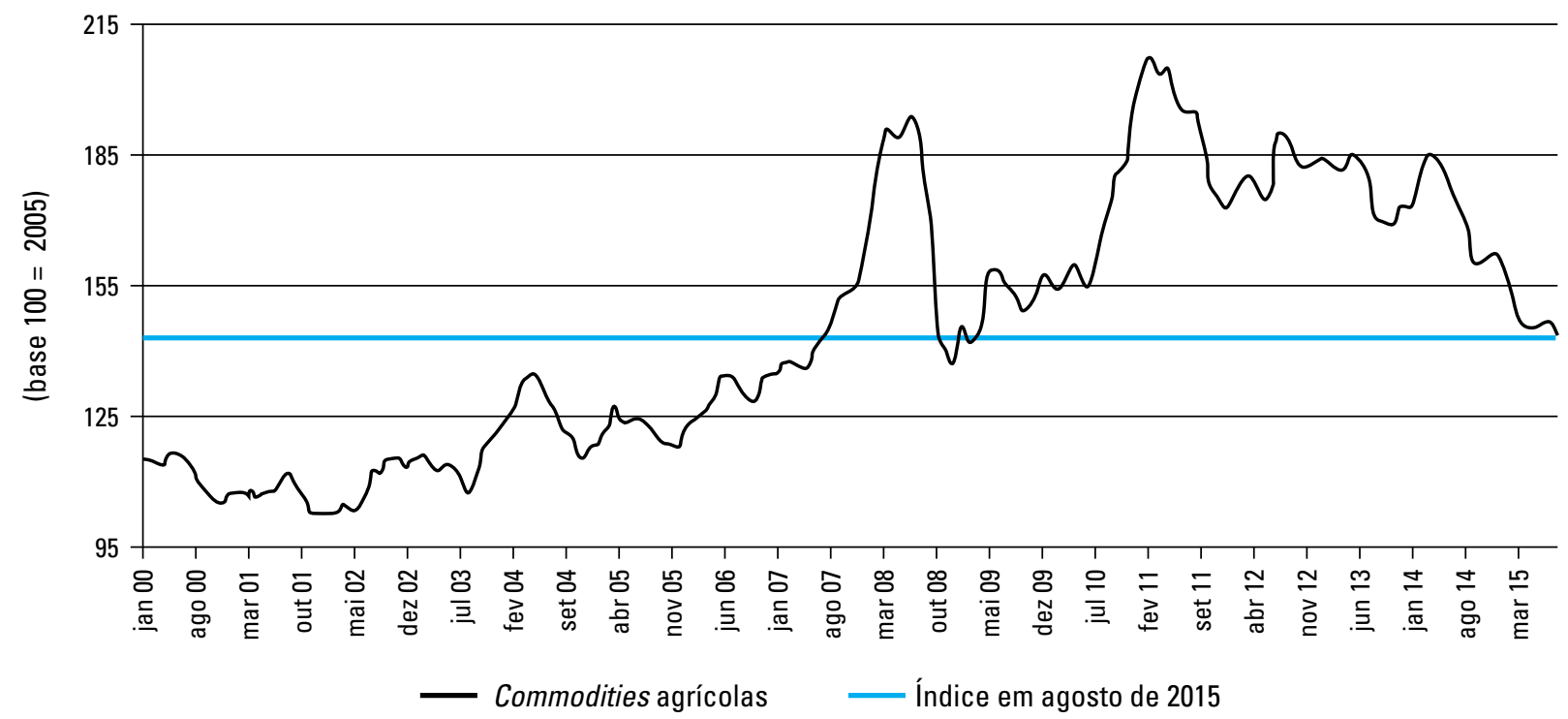

Fonte.: SERIGATI, 2015.

Gráfico 2 • Preço da soja anual, Bolsa de Chicago, em US Dólares (1997 - 2017)

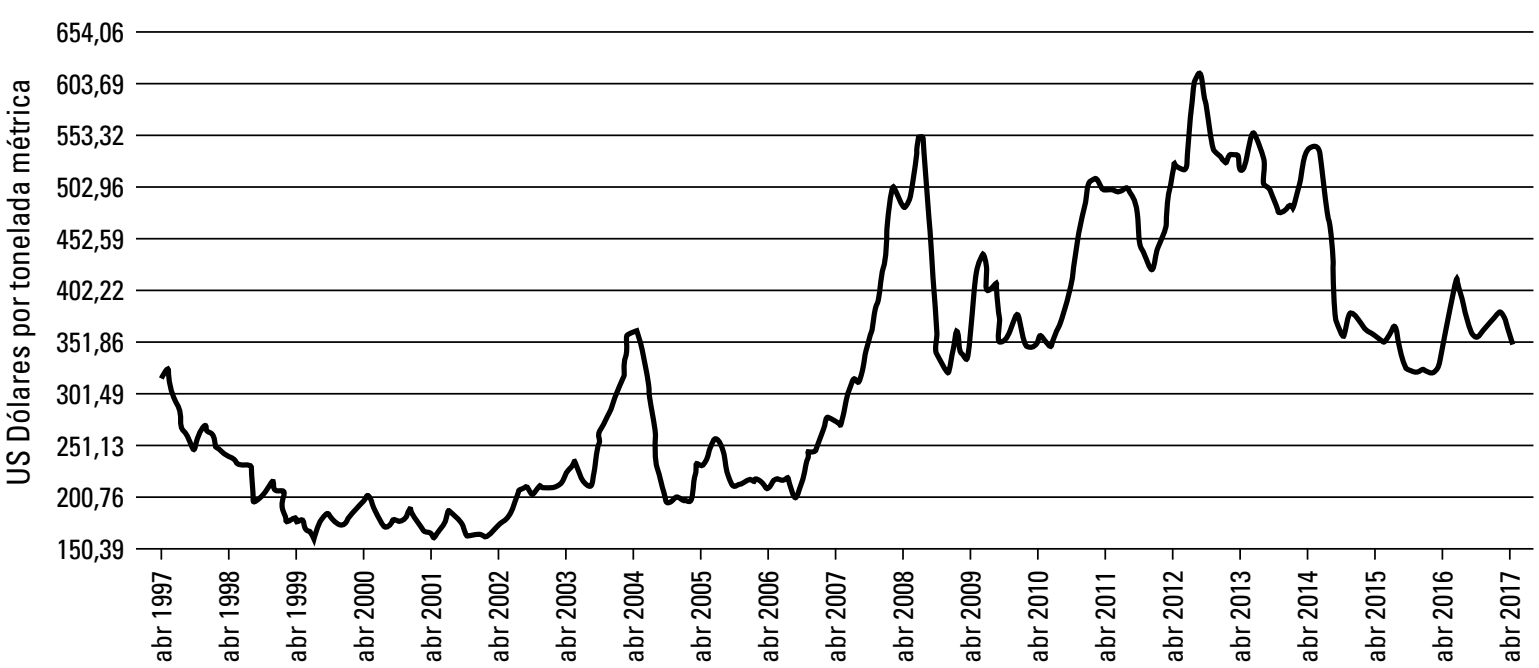

Fonte: Banco Mundial, 2017

Com a crise econômica mundial, a partir de 2008 (KLIMAN, 2012), iniciou-se uma queda brusca nos preços das commodities (KURZ, 2011; DELGADO, 2012), já que capitais especulativos migraram para títulos de baixo risco e de baixa rentabilidade, como o são os títulos do governo estadunidense. Após uma primeira queda, os preços retomaram um processo inflacionário, buscando melhores rendimentos especulativos, mas a partir de meados da safra 2012/2013 voltaram a cair, acelerando tal queda de forma acentuada a partir de 2014.

Atualmente, quais são os principais fatores que influenciam a formação dos preços agrícolas? Os fundamentos do lado real da economia, isto é, variáveis associadas com as condições de oferta e demanda dessas commodities, ou as flutuações nos mercados financeiros, refletindo, principalmente, estratégias espe- 
culativas? Essas questões ficaram ainda mais evidentes em razão do aumento da volatilidade dos preços agrícolas na última década: períodos de forte crescimento foram interrompidos por abruptas e profundas quedas que, por sua vez, foram sucedidas por intensos períodos de recuperação.

Esta dinâmica fica clara ao se observar a evolução do índice de preços de commodities agrícolas e minerais, sem petróleo, divulgado mensalmente pelo Fundo Monetário Internacional (FMI). Este índice é uma média dos preços das principais commodities transacionadas no mercado internacional, ponderados seus respectivos volumes de comércio. Ao analisar o comportamento deste índice de preços, fica claro que, entre 1991 e 2003, os preços das commodities agrícolas e minerais apresentaram suaves flutuações, com uma tendência ascendente até 1995/96 e descendente até 2003. A partir de 2003, porém, os preços apresentaram forte e constante crescimento até julho de 2008 (durante estes cinco anos, o valor do índice praticamente mais que dobrou). Em razão da crise econômica nos países centrais, com especial destaque para os Estados Unidos e para os países da União Europeia, de agosto a dezembro de 2008, isto é, em apenas cinco meses, os preços das commodities caíram em média $30 \%$, retornando aos patamares observados no início de 2006. É interessante observar que esta queda, embora intensa, foi muito rápida; a partir de março de 2009, os preços iniciaram um processo de recuperação, crescendo ininterruptamente até abril de 2011.

É também importante mencionar que em abril de 2010 o índice de preços já tinha superado o pico de 2008 e no começo de 2011 estabeleceu novo recorde. Todavia, novamente, conforme se deteriorava a solvência de alguns países na periferia da zona do euro, os preços das commodities voltaram a registrar forte declínio, voltando a crescer somente entre dezembro e abril de 2011, período que coincide com duas rodadas de empréstimos a juros "de pai para filho" que o Banco Central Europeu promoveu para os bancos da região. Após passar a euforia dos empréstimos, os preços das commodities voltaram a cair (SERIGATI, 2012, apud, PITTA, 2016, p. 248).

Embora as commodities agrícolas, na média, tenham apresentado uma tendência de queda desde o seu pico, em fevereiro de 2011, esse declínio, a partir do primeiro semestre de 2014, tornou-se bem mais intenso (SERIGATI, 2015).

Naquele primeiro momento de deflação dos preços nestes mercados, diversas empresas faliram, muitas especulando com câmbio ao utilizarem-se dos empréstimos que haviam adquirido sobre sua promessa de produção futura (FARHI; BORGUI, 2009). Muitas foram, inclusive, as usinas de cana-de-açúcar a irem à bancarrota, em razão de seu alto endividamento lastreado nas altas dos preços futuros de açúcar nos anos anteriores (PITTA, 2016). Após 2012 e 2013 a situação se aprofundou ainda mais (CERDAS, 2015; PITTA, 2016) e a crise econômica brasileira atual tem relação importante com o movimento do capitalismo a nível mundial por nós aqui apresentado.

Assim, a prosperidade brasileira dos últimos anos assenta em pés de barro. O sucesso de exportação baseia-se principalmente em matérias-primas industriais e agrícolas, como minério de ferro, açúcar, etanol (biocombustível a partir de cana de açúcar), café e carne. A forte subida dos seus preços estimulou o crescimento e as reservas de divisas. Com uma recessão global esse processo pode ser rapidamente revertido (KURZ, 2011, p. 1).

O momento de subida dos preços de commodities, desse modo, resultou em profunda expansão dos níveis de área plantada, produção e produtividade das agroindústrias no Brasil. Foi neste período que a produção de soja alcançou definitivamente o MATOPIBA (PITTA; MENDOÇA, 2015), não mais como ocupação da fronteira agrícola a promover a formação do mercado nacional de trabalho e de terra, como nos anos 1950/1960, como vimos anteriormente, mas agora como acumulação de ativos financeiros a servirem de lastro para a nova promessa de expansão da produção de 
tais ativos movida pela inflação do preço destes nos mercados financeiros de derivativos mundiais. Entre 2000 e 2014, a área plantada com soja aumentou 253\% (CERDAS, 2015). Neste caso, a área plantada foi de 1 para 3,4 milhões de hectares.

Tabela 1: Produção, Área e Produtividade da Soja no Brasil - safras 1994/95 a 2015/2016

\begin{tabular}{l|c|c|c|c|c|c}
\hline Ano-Safra & $\begin{array}{c}\text { Produção } \\
\text { (mil toneladas) }\end{array}$ & $\begin{array}{c}\text { Produção } \\
\%\end{array}$ & $\begin{array}{c}\text { Área Plantada } \\
\text { (mil ha })\end{array}$ & $\begin{array}{c}\text { Área } \\
\%\end{array}$ & $\begin{array}{c}\text { Produtividade } \\
(\mathrm{kg} / \mathrm{ha})\end{array}$ & $\begin{array}{c}\text { Produtividade } \\
\%\end{array}$ \\
\hline $1994 / 95$ & $25.934,1$ & 3,5 & $11.678,7$ & 1,5 & 2.221 & 1,9 \\
\hline $1995 / 96$ & $23.189,7$ & $-10,6$ & $10.663,2$ & $-8,7$ & 2.175 & $-2,1$ \\
\hline $1996 / 97$ & $26.160,0$ & 12,8 & $11.381,3$ & 6,7 & 2.299 & 5,7 \\
\hline $1997 / 98$ & $31.369,9$ & 19,9 & $13.157,9$ & 15,6 & 2.384 & 3,7 \\
\hline $1998 / 99$ & $30.765,0$ & $-1,9$ & $12.995,2$ & $-1,2$ & 2.367 & $-0,7$ \\
\hline $1999 / 00$ & $32.890,0$ & 6,9 & $13.622,9$ & 4,8 & 2.414 & 2,0 \\
\hline $2000 / 01$ & $38.431,8$ & 16,8 & $13.969,8$ & 2,5 & 2.751 & 14,0 \\
\hline $2001 / 02$ & $42.230,0$ & 9,9 & $16.386,2$ & 17,3 & 2.577 & $-6,3$ \\
\hline $2002 / 03$ & $52.017,5$ & 23,2 & $18.474,8$ & 12,7 & 2.816 & 9,3 \\
\hline $2003 / 04$ & $49.792,7$ & $-4,3$ & $21.375,8$ & 15,7 & 2.329 & $-17,3$ \\
\hline $2004 / 05$ & $52.304,6$ & 5,0 & $23.301,1$ & 9,0 & 2.245 & $-3,6$ \\
\hline $2005 / 06$ & $55.027,1$ & 5,2 & $22.749,4$ & $-2,4$ & 2.419 & 7,8 \\
\hline $2006 / 07$ & $58.391,8$ & 6,1 & $20.686,8$ & $-9,1$ & 2.823 & 16,7 \\
\hline $2007 / 08$ & $60.017,7$ & 2,8 & $21.313,1$ & 3,0 & 2.816 & $-0,2$ \\
\hline $2008 / 09$ & $57.165,5$ & $-4,8$ & $21.743,1$ & 2,0 & 2.629 & -7 \\
\hline $2009 / 10$ & $68.688,2$ & 20,2 & $23.467,9$ & 7,9 & 2.927 & 11 \\
\hline $2010 / 11$ & $75.324,3$ & 9,7 & $24.181,0$ & 3,0 & 3.115 & 6 \\
\hline $2011 / 12$ & $66.383,0$ & $-11,9$ & $25.042,2$ & 3,6 & 2.651 & -15 \\
\hline $2012 / 13$ & $81.499,4$ & 22,8 & $27.736,1$ & 10,8 & 2.938 & 11 \\
\hline $2013 / 14$ & $86.120,8$ & 5,7 & $30.173,1$ & 8,8 & 2.854 & $-2,9$ \\
\hline $2014 / 15$ & $96.228,0$ & 11,7 & $32.092,9$ & 6,4 & 2.998 & 5,1 \\
\hline $2015 / 16$ & $95.434,6$ & $-0,8$ & $33.251,9$ & 3,6 & 2.870 & $-4,3$ \\
\hline
\end{tabular}

Fonte: organizado por Cecília Vecina a partir de dados do CONAB.

Ao observarmos o Gráfico 2, que segue aliás de maneira muito próxima a oscilação dos preços das commodities em geral apresentada pelo Gráfico 1, podemos observar a determinação dos momentos altistas e baixistas conforme investimentos nestes mercados, como destacamos anteriormente.

Não caberia aqui percorrer de maneira minuciosa as oscilações para produção, área plantada e produtividade da soja brasileira que a Tabela 1 nos apresenta. Cabe ressaltarmos, entretanto, que os níveis de produtividade das lavouras de soja brasileiras, em geral, são dos mais elevados do mundo (ALVES, 2006). Logo após a retomada dos créditos subsidiados do BNDES, a partir de 1999, para as agroindústrias brasileiras, a produtividade da soja brasileira (2000/2001 e 2002/2003) alcançou níveis que só viriam a ser superados após os picos dos preços da soja após a crise de 2008 , e mesmo assim, não de forma permanente. Por outro lado, a expansão da produção e da produtividade da soja ocorreram concomitantemente à expansão em área como ativo financeiro e capaz de lastrear as promessas de aumento de produção. 
Tal movimento da agroindústria (não exclusivo para a soja) no campo brasileiro necessitou, assim, de um crescimento em níveis exponenciais relacionados à capacidade de expansão dos capitais financeiros e para isso não bastava o aumento de sua produtividade, mas também da área plantada com tais commodities. Combinou-se assim, aumento da produção e da produtividade em níveis que também moveram a subida inflacionária do preço da terra como ativo financeiro (ver Tabela 2, abaixo).

A inflação do preço da terra como ativo financeiro pôde, assim, ser incorporada, inclusive, como forma de inflacionar os preços das ações das empresas produtoras de commodities que passaram a abrir capital na BM\&F/BOVESPA (Bolsa de Valores, Mercadorias e Futuros de São Paulo), aproveitando o momento de alta de seus preços, aberturas que foram se estancando conforme os desdobramentos da crise de 2008 se mostravam presentes.

Após a crise de 2008 podemos constatar uma brusca queda nos preços da soja nos mercados de futuros internacionais (safra 2008/2009), assim como a queda no montante de soja produzido nacionalmente e em seus níveis de produtividade. A área, por sua vez, expandiu-se em $2 \%$, de 21,3 para 21,7 milhões de hectares, mesmo com o cenário adverso:

[...] A restrição do crédito influenciou a safra 2008/2009. As dívidas que somavam $\mathrm{R} \$ 10$ bilhões somente em Mato Grosso limitaram muito a liberação de recursos públicos na área do cerrado. [...] Todavia, os produtores que deixaram para comprar os fertilizantes às vésperas da semeadura, por falta de crédito ou de planejamento, deverão reduzir seus pacotes [tecnológicos] e ainda assim ter rentabilidade quase nula. Em alguns casos poderá até ser negativa (COLLOSSI, 2009, pg. 434).

As safras posteriores $(2009 / 2010,2010 / 2011,2012 / 2013)$ poderiam nos dar a impressão de resolução de tal cenário de crise econômica, já que veremos uma ampliação da produção, área e produtividade da soja. Vale ressaltar, porém, que a acumulação capitalista nos EUA e Europa entrou em recessão (KLIMAN, 2012), reduzindo o ritmo de crescimento do consumo de soja a nível mundial. Isso ocorreu também pois o próprio crescimento da economia chinesa, principal importadora da soja brasileira, diminuiu de ritmo, em razão de seu entrelaçamento econômico com os mercados consumidores estadunidenses e europeus (e também como credores destes países) em crise (KONICZ, 2015).

Nos últimos anos, porém, com a retomada da queda dos preços mundiais das commodities, que como já vimos retomou a tendência especulativa baixista (SERIGATI, 2015), com a soja apresentando aprofundamento de tal tendência a partir de meados de 2014 (ver Gráfico 2, acima), diversos produtores de soja vêm apresentando dificuldades para manter seus níveis de acumulação capitalista. Estudo recente de Mauro Osaki, apresentado pela reportagem a seguir, explicita a relação especulativa com o câmbio e ressalta o contexto crítico da safra atual, 2016/2017, para a produção de soja no Brasil:

[...] A soja tem sido destaque negativo puxado justamente pelo aumento dos custos de produção. Apesar da supersafra esperada, algo em torno de 107 milhões de toneladas, foi identificado que o preço pago ao produtor caiu, e a receita líquida total está próxima de zero. [...] Diante desta constatação o pesquisador destaca que a situação deve servir de alerta ao país, já que novos investimentos 
podem ficar comprometidos. "O produtor foi compensado nessas últimas duas safras, principalmente em relação à taxa de câmbio que deu essa falsa impressão de que a rentabilidade estava positiva, mas agora começa a entrar um pouco mais dentro da realidade", garante ele (SOJABRASIL, 23 de abril de 2017).

Como pudemos observar por meio da Tabela 1, mesmo nas safras em que houve queda de produção e de produtividade de soja - como em 2008/2009, 2011/2012, 2013/2014 (queda da produtividade) e na última safra, a de $2015 / 2016$, com queda de $0,8 \%$ de produção e $4,3 \%$ na produtividade - a expansão da área com soja não deixou de ocorrer.

Em momentos em que as novas áreas de fronteira são incorporadas para a produção de soja, com desmatamento direto do Cerrado, há um hiato de alguns anos, entre 5 a 10 anos, para que tal terra se aproxime da média de produtividade nacional e mundial e faça aquela terra ser capaz de efetivamente acumular capital. Quando os preços de mercado de uma dada mercadoria caem, os piores solos deixam de render acima dos custos de produção, tornando a referida terra improdutiva em termos capitalistas. Enquanto os preços da mercadoria em questão estão em ascensão, terras piores podem ser incorporadas à produção. Quando os preços caem, tais terras passam a dar prejuízo e podem permanecer em funcionamento por um certo período de tempo, tendo de ser desativadas posteriormente. Porém, em um momento em que a terra funcione como ativo financeiro à parte, com inflação de seu preço apesar da queda nos preços das commodities que nela podem ou não ser produzidas, a comercialização da mesma pode ocorrer de forma independente (PITTA; CERDAS; MENDONÇA, 2018).

Assim, a incorporação de novas áreas, com abertura de novas terras, serve como possibilidade de ampliação de produção de soja a lastrear financiamentos sobre a subida do preço desta commodity, serve como banco de terras a inflar o portfólio das empresas, lastreando a subida do preço de suas ações em bolsa de valores, e serve também como ativo financeiro propriamente dito, atuando relativamente de maneira independente em relação ao preço das mercadorias que podem ser produzidas ali. Tal possibilidade está no cerne da criação das imobiliárias agrícolas transnacionais, o que abordaremos a seguir como síntese atual do processo histórico de crise que viemos descrevendo até aqui.

Tabela 2: Comparação da Inflação de ativos Financeiros no Brasil (2013-2016 e 2006-2016)

\begin{tabular}{c|c|c}
\hline Indicador & $\begin{array}{c}\text { Valorização no período (3 } \\
\text { anos })\end{array}$ & $\begin{array}{c}\text { Valorização no período } \\
(10 \text { anos })\end{array}$ \\
\hline Dolar & $39 \%$ & $52,70 \%$ \\
\hline Renda Fixa (CDI) & $43,51 \%$ & $183 \%$ \\
\hline BOVESPA & $28,95 \%$ & $38,10 \%$ \\
\hline Ouro & $30,33 \%$ & $164 \%$ \\
\hline Terra & $15,66 \%$ & $220 \%$ \\
\hline
\end{tabular}

Fonte: organizado por Cássio A. Boechat a partir de dados do SLC, 2017, p 62.

Ao observarmos os Gráficos 1 e 2 e sua relação com a Tabela 2 acima (apreciação dos preços das terras no Brasil, farmland em inglês), 
verificamos que mesmo após a queda nos preços das commodities, pode-se perceber a continuidade da subida do preço da terra, ocorrendo, assim, um descolamento entre os lucros obtidos com uma produção de uma mercadoria em determinado tipo de solo e a renda capitalizada da terra, a partir da negociação da mesma também como um tipo de ativo financeiro (DELGADO, 2012 e PITTA e MENDONÇA, 2015) ${ }^{11}$. Sobre a primeira década do século XXI, Delgado (2012) observa o que segue:

\begin{abstract}
O movimento de expansão da exportação na década passada, com destaque à exportação de produtos primários que demonstramos na seção precedente, suporta um processo intenso de valorização das terras agropecuárias e irá propiciar uma clara reversão do ciclo de desvalorização, observado nos anos 1990 [...] (DELGADO, 2012, p. 97).

O processo de relançamento da valorização fundiária, visto que este mesmo surto fora observado no período $1967 / 86$, reflete o boom de commodities mundiais da década [de 2000] (DELGADO, 2012, p. 98, apud PITTA, 2016, p. 256, nota 142).
\end{abstract}

Saskia Sassen (2016), ao analisar a transformação da terra em ativo financeiro, a partir da criação de um mercado global de terras e também da criação de empresas transnacionais imobiliárias agrícolas (ver PITTA; MENDONÇA, 2015), observa o seguinte sobre a aquisição das terras por estas transnacionais, exponencialmente mais relevantes a partir da crise de 2008:

\begin{abstract}
A aquisição de terra estrangeira não é um acontecimento solitário. Ela requer, e por sua vez estimula, a criação de um vasto mercado global de terras. Implica o desenvolvimento de uma infraestrutura de serviços igualmente vasta para permitir vendas e aquisições, obter a posse ou os direitos de arrendamento, desenvolver instrumentos legais apropriados e até pressionar pela criação de novas leis que acomodem essas compras em um país soberano. Essa infraestrutura vai muito além do que apoiar o mero ato da compra. Não apenas facilita, como também estimula novas aquisições de terras por parte de estrangeiros. Esse setor de serviços especializados cada vez mais sofisticado inventa novos tipos de contrato e formas de propriedade e cria instrumentos inovadores de contabilidade, legislação e de seguros. À medida que se desenvolve, ele depende, por sua vez, de novas aquisições de terra estrangeira como fonte de lucros. Vemos o começo de uma mercantilização em grande escala, o que pode levar à financeirização da mercadoria que continuamos a chamar simplesmente de terra (SASSEN, 2016, p. 100).
\end{abstract}

Relacionando a queda nos preços das commodities, principalmente após 2008/2009 e com maior explicitação, após 2012/2013 (Gráficos 1 e 2), com a subida nos preços das terras, Delgado esclarece:

\footnotetext{
Outra forma sub-reptícia de produzir valorização financeira na crise econômica, favorecendo, no caso, outro título patrimonial estratégico, é combinar medidas regulatórias com outras não regulatórias para impedir que a queda nos preços das "commodities" desvalorize os preços das terras rurais, impactados por mais de uma década do "boom das commodities".

$[\ldots]$

Proprietários de ativos financeiros e de recursos naturais - terras, recursos hídricos, minas e campos petroleiros, normalmente estariam preocupados com a reversão dos preços externos das "commodities". Alguns de fato sentiram a crise, com é o caso das grandes empresas do setor - PETROBRÁS, Vale do Rio Doce-ALBRAS-ALUNORTE etc., cujos negócios externos encolheram. Mas há uma via secreta de apropriação de fundos públicos - a dívida pública e o mercado de terras - que vêm sendo mantido artificialmente valorizados, para salvar a renda fundiária e a renda financeira em uma economia de crescimento zero ou negativa (DELGADO, 2015).
}

Não por acaso, diversas transnacionais produtoras de commodities, como a Cosan S/A, a SLC Agrícola S/A, passaram, a partir de meados de
11. Para o acesso a outras interpretações acerca do processo de transformação da terra em ativo financeiro, com cerne na região do MATOPIBA, ver Pereira e Pauli (2016). 
12. Ver as seguintes notícias: “Megaprodutores consolidam a última fronteira" (Valor Econômico, 01 de abril de 2013) e "10 grupos têm um terço da nova fronteira da soja" (Valor Econômico, 01 de abril de 2013).
$2008 / 2009^{12}$, a investir na terra como principal ativo financeiro de seus negócios. Em alguns casos, como a Cosan S/A e a SLC Agrícola S/A, as empresas de capital aberto em bolsa de valores e constituídas no formato de holdings, criaram braços como transnacionais imobiliárias agrícolas a fim de negociarem a terra agrícola como negócio exclusivo de empresas como a Radar Propriedades Agrícolas S/A e a SLC LandCo., de propriedade respectivamente das duas empresas acima citadas em sociedade com fundos de pensão ou de investimentos internacionais (PITTA; MENDONÇA, 2015).

Ainda dentre outras transnacionais que ocuparam as chapadas do MATOPIBA no século XXI com significativo aumento desta ocupação a partir de 2008/2009 é importante destacarmos a BrasilAgro, a TibaAgro, por meio do Fundo VisionBrazil Gestão de Investimentos e Participações Ltda, a Sollus Capital, relacionada com a Ceagro (com capital da Mitsubishi-Japão e do Grupo Los Grobo-Argentina); a XingúAgri (com negócios com a Multigrain-EUA/Mitsui-Japão e com a SLC Agrícola-Brasil); Adecoagro (com capital do megainvestidor financeiro George Soros); a Agrinvest (com capital dos fundos Ridgefield-EUA e Touradji-Brasil; a CalyxAgro (vinculada ao Grupo Louis Dreyfus Commodities-Holanda e ao fundo PineBridge Investment); o Grupo Colorado (com capital dos fundos Global Oportunity e Black Rock); a Insolo AgroIndustrial (com capital da Universidade de Harvard) ainda sem mencionar com maior profundidade as tradings como a Bunge e a Cargill (PITTA; CERDAS; MENDONÇA, 2018).

Como vimos anteriormente, a subida dos preços das commodities nos mercados de futuros internacionais moveu a ocupação de novas áreas para sua produção, mesmo que mantendo relativamente alta a produtividade, altos índices de mecanização e baixa incorporação de trabalho no processo produtivo. Foi assim que a produção de soja atingiu com profundidade no começo do século XXI áreas do MATOPIBA e passou a ocupar terras devolutas de chapada, muitas delas utilizadas secularmente por camponeses e pequenos produtores rurais. Estas áreas, com Cerrado ainda nativo, utilizado de forma comunal pelas populações rurais locais, ao serem desmatadas e inseridas no mercado de terras como fazendas formadas, podem ser incorporadas a um custo muito baixo e depois precificadas, elevando a renda capitalizada quando de sua venda, após aumentar sua produtividade, por meio do preparo do solo e de formação de estruturas internas para produção de soja, no caso da região em questão.

A mera aquisição da terra e sua venda posterior, após a subida de seu preço no mercado de terras, também é possível, mesmo sem a terra estar produzindo nada, como é o caso da Radar S/A no MATOPIBA (PITTA; MENDONÇA, 2015). Seu caso é significativo, já que de produtora de cana, açúcar e etanol, passou a investir em terras em áreas produtoras de soja. Ao final de 2016, a Cosan S/A vendeu sua parte da RADAR S/A para seu sócio, o fundo de pensão estadunidense TIAA-CREF (Valor Econômico, 30 de setembro de 2016), realizando os rendimentos com a venda da terra a preços mais altos do que as adquiriu (justamente a partir da criação desta empresa, em 2008). A própria demanda pela terra como ativo financeiro, inclusive em razão da demanda pelas transnacionais imo- 
biliárias agrícolas ou land companies, move a subida dos seus preços no mercado de terras nacional e faz da mesma um negócio especulativo à parte dos demais ativos.

Gráfico 3 • Preços de terra de alta produtividade MATOPIBA (2003 - 2016) (R\$/ha)

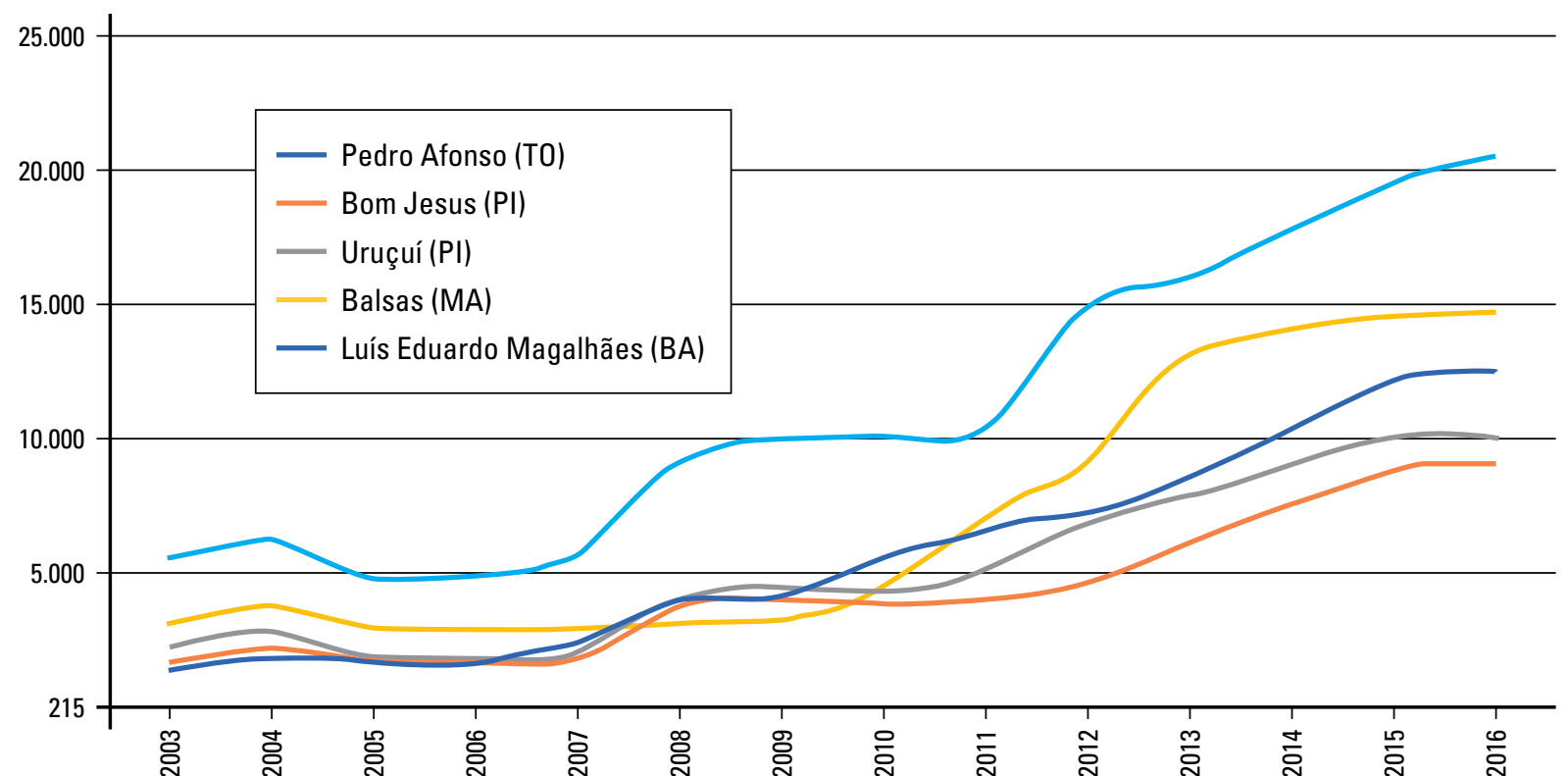

Fonte: organizado por Débora Lima a partir de dados do Informa Economics/FNP. Preços corrigidos pelo IGP-M (índice Geral de Preços do Mercado) para abril de 2015. Atualização para os anos de 2015 e 2016 por Tim Steinweg e Hilde van Dijkhorst (AidEnvironment-Holanda). Ver $<$ http://www.informaecon-fnp.com>.

O Gráfico 3 acima mostra a vertiginosa subida dos preços das terras desde o início do boom das commodities, nas principais áreas produtoras de soja do MATOPIBA. Mesmo após as quedas nos preços internacionais de commodities nos últimos anos, os preços das terras continuam subindo. A consequente subida dos preços das terras, por sua vez, também moveu o aumento de processos de grilagem de terras, mesmo que nem sempre sejam diretamente transnacionais proprietárias fundiárias que realizam o processo inicial de apropriação ilegal de terras, mas terceiros, impulsionados pelas altas especulativas de seus preços, visando sua comercialização. O próprio processo de subida dos preços das terras movidos pela demanda pelas mesmas fomenta o aumento dos processos de grilagem de terras, expropriação de camponeses e desmatamento de áreas de Cerrado, como é o caso aqui estudado do MATOPIBA. Desse modo, o tratamento dado ao caso particular do MATOPIBA permite inseri-lo nos debates e processos mais amplos abarcados pela literatura recente sobre land grabbing, evidenciando uma inflexão financeira nos últimos anos que requalifica processos anteriores.

Conclusão

A crise econômica de 2008 gerou uma mudança no perfil do agronegócio no Brasil e estimulou a presença de empresas transnacionais de diferentes setores, não só agrícolas, mas também financeiras. Tal processo 
estimulou fusões e aquisições, causando maior concentração de capitais. As empresas optam por tal procedimento com a intenção de aumentar seu capital e demais ativos, como máquinas, terras, subsidiárias, entre outros. Assim, o preço de suas ações passa a ser parte fundamental do valor de mercado e torna-se parâmetro para que consigam crédito.

A formação de novas fazendas ocorre geralmente em terras públicas, por meio do cercamento de uma área até então sem título de propriedade. Na maioria das vezes isso acontece sobre terras devolutas, do Estado, nas quais pequenos agricultores têm vivido e produzido alimentos algumas vezes há centenas de anos por meio da posse. A principal maneira de se formar uma fazenda sobre terras devolutas é através da grilagem, que consiste no ato ilegal de forjar a titularidade e cercá-la, expulsando os agricultores locais para posteriormente vender ou arrendar a "nova" propriedade como se estivesse legalizada.

Os impactos da expansão do agronegócio e da especulação com terras no MATOPIBA - especulação fomentada inclusive pelas imobiliárias agrícolas transnacionais que investem na terra como ativo financeiro nesta região - geram expropriação das populações camponesas, indígenas e quilombolas. A expropriação das comunidades causa pobreza, fome e necessidade de seus moradores se submeterem a condições degradantes de trabalho nas fazendas, muitas vezes análogo à escravidão, ou a migrarem para as cidades. A elevação do desemprego piora as condições habitacionais nas cidades, como resultado da expansão do capital financeiro e especulativo no campo brasileiro.

É possível entender o papel do capital financeiro como uma forma de "terceirização" nos negócios com terras. Da mesma forma como o trabalho terceirizado no corte de cana é utilizado para isentar usineiros da responsabilidade pelas condições degradantes e dos casos de trabalho escravo. O mecanismo de "terceirização" consiste em criar diversas empresas com os mesmos administradores, assim como subsidiárias, fazendo parecer que são de proprietários distintos.

Estas são algumas das principais tendências identificadas na pesquisa apresentada no presente artigo, que demonstra a relação entre o capital financeiro internacional, o mercado de terras e seus impactos no campo brasileiro.

Referências

ALVES, Vicente Eudes Lemos. Mobilização e modernização nos cerrados piauienses: formação territorial no império do agronegócio. São Paulo: 2006. Tese (Doutorado em Geografia), FFLCH-USP

BERNARDES, Júlia Adão. "Modernização agrícola e trabalho no Cerrado brasileiro”. Anais do IX Colóquio Internacional de Geocrítica, 28 de maio a 1 de junho de 2007. Disponível em: $<$ http://www.ub.edu/geocrit/9porto/juliaad.htm>. Acesso em: jul. 2017.

BANCO MUNDIAL. Indexmundi: commodities, 2017. Disponível em: <http://www.indexmundi.com/commodities/?commodity=soybeans\&months=240>. Acesso em: mai. 2017.

BOECHAT, Cássio Arruda. O colono que virou suco: terra, trabalho, Estado e capital na modernização da citricultura paulista. São Paulo, 2014, Tese (doutorado em geografia). FFLCH - USP, 2014.

BOECHAT, Cássio A., PITTA, Fábio T. e TOLEDO, Carlos de A. "Land grabbing e crise do capital: possíveis intersecções dos debates”. Rio de Janeiro: Revista GEOgraphia, UFF, v. 19, n ${ }^{\circ}$ 40, 2017, p. 75-91. 
BOECHAT, Cássio A., LEITE, Ana Carolina G.; e TOLEDO, Carlos de A. "Archéologie de la question agraire au Brésil: du labor grabbing au land grabbing”. Paris : EchoGéo, v. 41, 2017.

BRASIL. II Plano Nacional de Desenvolvimento (1975-1979). Brasília, Serviço Gráfico do IBGE, 1975. 150p

BRENNER, Robert. O boom e a bolha: os Estados Unidos na economia mundial. Rio de Janeiro: Editora Record, 2003.

CÂMARA DOS DEPUTADOS. Câmara dos Deputados: projeto de resolução 159. Brasília: Centro Gráfico do Senado Federal, 1980. 8p.

CAMARGO, Paula. Organização produtiva e socioterritorial da agroecologia - o MST e sua Cooperativa Agropecuária Vitória, Paranacity-PR. São Paulo: 2010. Trabalho de Graduação Individual (Graduação em Geografia). FFLCH-USP.

CERDAS, Gerardo. A dupla serpente: Estado e agroindústria sucroenergética brasileira na construção de uma nova matriz de inserção global (2003-2014). Rio de Janeiro: 2015. Tese (Doutorado em Ciências Sociais), UFRRJ.

COLUSSI, Pedro. AgriAnual 2009. São Paulo: Instituto FNP, 2009.

COLUSSI, Pedro. AgriAnual 2010. São Paulo: Instituto FNP, 2010.

COMPANHIA NACIONAL DE ABASTECIMENTO (CONAB). Agricultura e abastecimento em boa companhia. Disponível em: <https://www.conab.gov.br> Acesso em: 05 dez. 2017.

DAVIDOFF, Paulo. Dívida Externa e política econômica: a experiência brasileira nos anos 1970. São Paulo: Editora Brasiliense, 1984.

DELGADO, Guilherme. Capital Financeiro e Agricultura: 1965-1985. São Paulo: Ícone, 1985.

DELGADO, Guilherme. Do capital financeiro na agricultura à economia do agronegócio mudanças cíclicas em meio século. Porto Alegre: Editora UFRGS, 2012.

DELGADO, Guilherme. "Apropriação financeira na crise”. Correio da Cidadania, São Paulo, 11 de agosto de 2015. Disponível em: <http://www.correiocidadania.com.br/index. php?option $=$ com_content $\&$ view $=$ article $\& i d=11016: 2015-08-11-17-27-52 \&$ catid $=72$ :imagens-rolantes>. Acesso em: jul 2017.

FARHI, Maryse; BORGUI, Roberto Alexandre. "Operações com derivativos financeiros das corporações de economias emergentes no ciclo recente”. Anais do II Encontro Internacional da Associação Keynesiana Brasileira, Porto Alegre, UFRGS, setembro de 2009. Disponível em: <http://www.ppge.ufrgs.br/akb/encontros/2009/02.pdf>. Acesso em: jul. 2017.

FURTADO, Celso. Formação econômica do Brasil. São Paulo: Publifolha, 2000.

GOLDENSTEIN, Lea; SEABRA, Manoel. "Divisão territorial do trabalho e nova regionalização”. Revista do Departamento de Geografia, USP, São Paulo, v. 1, 1982.

HARVEY, David. A produção capitalista do espaço. São Paulo: Annablume, 2005.

HARVEY, David. O enigma do capital e as crises do capitalismo. São Paulo: Boitempo, 2011.

HEREDIA, Beatriz; LEITE, Sérgio Pereira e PALMEIRA, Moacir. "Sociedade e economia do agronegócio no Brasil”. Revista Brasileira de Ciências Sociais. v. 25, n. 74, 2010, p. 159-196.

HUDSON, Michael. The bubble and beyond: fictitious capital, debt deflation and global crisis. Dresden, Alemanha: Editora ISLET, 2012.

JAPAN INTERNATIONAL COOPERATION AGENCY (JICA). Economic and social impacts of Agricultural Development of the Cerrado. Tóquio: JICA, 2017.

KLIMAN, Andrew. The failure of capitalist production: underlying causes of the great recession. Londres: PlutoPress, 2012.

KONICZ, Thomasz. "Estará a China na iminência de um colapso? O crescimento da economia chinesa financiado pelo endividamento não aguenta mais”. Konkret, Alemanha, maio de 2015. Disponível em: <http://www.obeco-online.org/tomasz_konicz4.htm>. Acesso em: jun. 2017.

KURZ, Robert. "A ascensão do dinheiro aos céus: os limites estruturais da valorização do capital, o capitalismo de casino e a crise financeira global”. 1995. Disponível em: <o-beco. planetaclix.pt/rkurz101.htm>. Acesso em: jul. 2017.

KURZ, Robert. O colapso da modernização: da derrocada do socialismo de caserna à crise da economia mundial. 5. ed. São Paulo: Paz e Terra, 1999.

KURZ, Robert. O fim do boom das matérias-primas. Lisboa, 2011. Disponível em: http://o-beco.planetaclix.pt/rkurz395.htm. Acesso em: jul. 2017. 
LEITE, Ana Carolina Gonçalves. O campesinato no Vale do Jequitinhonha: da sua formação no processo de imposição do trabalho à crise da (sua) reprodução capitalista. São Paulo, 2015. Tese (doutorado em Geografia). FFLCCH-USP. Disponível em: < http://www. teses.usp.br/teses/disponiveis/8/8136/tde-05082015-124614/pt-br.php>. Acesso em: jul. 2017.

MARTINS, José de Souza. O cativeiro da terra. São Paulo: Hucitec, 2000.

MARX, Karl. O Capital - Crítica da Economia Política. Livro I, Tomo II. São Paulo: Abril Cultural, 1984 (Série "Os Economistas").

MARX, Karl. O Capital - Crítica da Economia Política. Livro III, Tomo II. São Paulo, Abril Cultural, 1985 (Série "Os Economistas").

MENDONÇA, Maria Luisa. Modo capitalista de produção e agricultura: a construção do conceito de agronegócio. São Paulo, 2013. Tese (Doutorado em Geografia), FFLCH, USP.

OLIVEIRA, Ariovaldo Umbelino. A mundialização da agricultura brasileira. São Paulo: Iandé Editorial, 2016.

OLIVEIRA, Francisco de. A economía da dependência imperfeita. São Paulo: Graal, 1977.

OLIVEIRA, Francisco de. Noiva da revolução/Elegia para uma re(li)gião: SUDENE, Nordeste, Planejamento e conflito de classes. São Paulo: Boitempo, 2008.

PELUSO, N.; LUND, C. "New frontiers of land control". The Journal of Peasant Studies, v. 38, n. 4, p. 667-681, 2011.

PEREIRA, Lorena Izá e PAULI, Lucas. "O processo de estrangeirização da terra e expansão do agronegócio na região do MATOPIBA". CAMPO-TERRITÓRIO: revista de geografia agrária. Edição especial, p. 196-224, jun., 2016.

PITTA, Fábio T. Modernização retardatária e agroindústria sucroalcooleira paulista: o Proálcool como reprodução fictícia do capital em crise. São Paulo, 2011. Dissertação (Mestrado em Geografia). FFLCH-USP. Disponível em: <http://www.teses.usp.br/teses/disponiveis/8/8136/tde-20102011-110312/pt-br.php>. Acesso em: 20 jul. 2017.

PITTA, Fábio T. As transformações na reprodução fictícia do capital na agroindústria canavieira paulista: do Proálcool à crise de 2008. São Paulo, 2016. Tese (doutorado em Geografia). FFLCCH-USP. Disponível em: <http://www.teses.usp.br/teses/disponiveis/8/8136/ tde-10052016-140701/pt-br.php>. Acesso em: jul. 2017.

PITTA, Fábio T. e MENDONÇA, Maria Luisa. A empresa Radar S/A e a especulação com terras no Brasil. São Paulo: Editora Outras Expressões, 2015. Disponível em: < https://social. org.br/files/pdf/RevistaREDE2015paranet2.pdf>. Acesso em: dez. 2017.

PITTA, Fábio T., CERDAS, Gerardo e MENDONÇA, Maria Luisa. Imobiliárias agrícolas transnacionais e a especulação com terras na região do MATOPIBA. São Paulo: Editora Outras Expressões, 2018.

SANTOS, Clóvis Caribé dos. "Programa de Cooperação Nipo-Brasileira para o Desenvolvimento dos Cerrados - PRODECER: um espectro ronda os cerrados brasileiros". Estudos Sociedade e Agricultura, vol. 24, n. 2, p. 384-416, outubro de 2016.

SASSEN, Saskia. Expulsões. São Paulo: Paz e Terra, 2016.

SAUER, S.; BORRAS JR., S. M. "Land grabbing” e "green grabbing”: uma leitura da "corrida na produção acadêmica" sobre a apropriação global de terras. Campo-Território - Revista de Geografia Agrária. Edição Especial, p. 6-42, 2016.

SCHOLZ, Roswitha. Cristóvão Colombo Forever: para a crítica das actuais teorias da colonização no contexto do "Colapso da modernização". Lisboa: 2016. Disponível em: <http://www. obeco-online.org/roswitha_scholz24.htm>. Acesso em: jul. 2017.

SERIGATI, Felippe. "Fundamentos $\mathbf{X}$ mercado financeiro". São Paulo: Agroanalysis, agosto de 2012. Disponível em: <http://www.agroanalysis.com.br/materia_detalhe. php?idMateria=1314>. Acesso em: jul. 2017.

SERIGATI, Felippe. “A última peça do velho cenário”. São Paulo: Agroanalysis, agosto de 2012. Disponível em: < http://www.agroanalysis.com.br/index.php/10/2015/mercado-negocios/ commodities-agricolas-a-ultima-peca-do-velho-cenario >. Acesso em: jul. 2017.

SILVA, José F. Graziano da. Progresso técnico e relações de trabalho na agricultura. São Paulo: Hucitec, 1982.

SILVA, Lauro Emilio Gonzalez da. Crises Financeiras Recentes e Poupança Externa. Tese de Doutorado, Fundação Getúlio Vargas - Escola de Economia de São Paulo, São Paulo, 2007, p. 142. 
SLC. Relatório de desempenho 1T17. Porto Alegre: SLC, 2017. Disponível em <http:// ri.slcagricola.com.br/>. Acesso em: jul. 2017.

SOJABRASIL. "Estudo garante que rentabilidade do sojicultor está próxima de zero". São Paulo: SojaBrasil, 23 de abril de 2017. Disponível em: http://www.projetosojabrasil.com.br/estudo-garante-que-rentabilidade-do-sojicultor-esta-proxima-a-zero/. Acesso em: jul. 2017.

STOLCKE, Verena. Cafeicultura: homens, mulheres e capital. São Paulo: Brasiliense, 1986.

THOMAZ JR., Antônio. Por trás dos canaviais: os nós da cana. São Paulo: Annablume/FAPESP, 2002.

VALOR ECONÔMICO. "Megaprodutores consolidam a última fronteira”. São Paulo: Valor Econômico, 01 de abril de 2013a. Disponível em: < http://www.valor.com.br/empresas/3067284/ megaprodutores-consolidam-ultima-fronteira $>$. Acesso em: jul. 2017.

VALOR ECONÔMICO. “10 grupos têm um terço da nova fronteira da soja”. São Paulo: Valor Econômico, 01 de abril de 2013b. Disponível em: <http://www.valor.com.br/empresas/3067336/dez-grupos-tem-um-terco-da-nova-fronteira-da-soja >. Acesso em: jul. 2017.

VALOR ECONÔMICO. “Cosan vende parte de suas ações na Radar para Mansilla por 1,065 bi”. São Paulo: Valor Econômico, 30 de setembro de 2016. Disponível em: < http://www.valor. com.br/empresas/4731589/cosan-vende-parte-de-suas-acoes-na-radar-para-mansilla-por-r-1065-bi>. Acesso em: jul. 2017.

WHITE, B.; BORRAS JR., S.; HALL, R; SCOONES, I.; WOLFORD, W. “The new enclosures: critical perspectives on corporate land deals”. The Journal of Peasant Studies, v. 39, n. 3-4, p. 619-647, 2016.

XAVIER, Carlos Vinicius; PITTA, Fábio T.; MENDONÇA, Maria Luisa. Monopólio da produção de etanol no Brasil: a fusão Cosan - Shell. São Paulo: Rede Social de Justiça e Direitos Humanos, Editora Outras Expressões, 2011. Disponível em: <https://www.social.org.br/revistacosanshel.pdf $>$. Acesso em: jul. 2017.

XAVIER, Carlos Vinicius; PITTA, Fábio T.; MENDONÇA, Maria Luisa. A Agroindústria canavieira e a crise econômica mundial. São Paulo: Rede Social de Justiça e Direitos Humanos, Editora Outras Expressões, 2012. Disponível em: <http://www.social.org.br/relatorioagrocombustiveis2012.pdf $>$. Acesso em: jul. 2017.

XAVIER, Carlos Vinicius; NAVARRO, Cristiano; PITTA, Fábio T.; MENDONÇA, Maria Luisa. Empresas Transnacionais e Produção de Agrocombustíveis no Brasil. São Paulo: Rede Social de Justiça e Direitos Humanos, Editora Outras Expressões, 2014. Disponível em: <https:// www.social.org.br/Empresas_transnacionais_e_producao_de_agrocombustiveis_no_Brasil. pdf $>$. Acesso em: jul. 2017. 